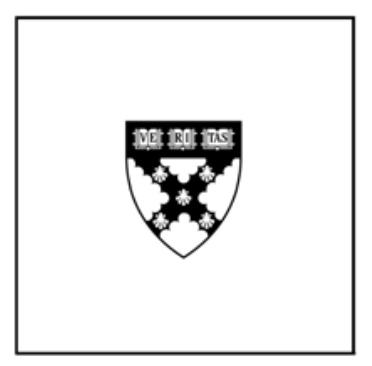

\title{
How the Zebra Got Its Stripes: Imprinting of Individuals and Hybrid Social Ventures
}

\author{
Matthew Lee \\ Julie Battilana
}

\section{Working Paper}

14-005

July 9, 2013 


\title{
HOW THE ZEBRA GOT ITS STRIPES: IMPRINTING OF INDIVIDUALS AND HYBRID SOCIAL VENTURES*
}

\author{
Matthew Lee \\ Harvard Business School \\ Cotting 316 \\ Boston, MA 02163 \\ Email: $\underline{\text { mlee@hbs.edu }}$ \\ Julie Battilana \\ Harvard Business School \\ Morgan 327 \\ Boston, MA 02163 \\ Email: jbattilana@hbs.edu
}

\begin{abstract}
Hybrid organizations that combine multiple, existing organizational forms are frequently proposed as a source of organizational innovation, yet little is known about the origins of such organizations. We propose that individual founders of hybrid organizations acquire imprints from past exposure to work environments, thus predisposing them to incorporate the associated logics in their subsequent ventures, even when doing so requires deviation from established organizational templates. We test our theory on a novel dataset of over 700 founders of social ventures, all guided by a social welfare logic. Some of them also incorporate a commercial logic along with the social welfare logic, thereby creating a hybrid social venture. We find evidence of three sources of commercial imprints: the founder's own, direct work experience, as well as the indirect influence of parental work experiences and professional education. Our findings further suggest that the effects of direct imprinting are strongest from the early tenure of for-profit experience, but diminish with longer tenure. In supplementary analyses, we parse out differences between the sources of imprints and discuss implications for how imprinting functions as an antecedent to the creation of new, hybrid forms.
\end{abstract}

Keywords: hybrid organizations; imprinting; institutional theory; social entrepreneurship

\footnotetext{
* We thank Jesse Chu-Shore, Elizabeth Hansen, Monica Higgins, Christopher Marquis, Anne-Claire Pache, Lakshmi Ramarajan, Metin Sengul, András Tilcsik, Melissa Valentine, Jennie Weiner, and participants in the following workshops and conferences: the Work, Organizations and Markets seminar at Harvard Business School, the OMTINSEAD-ASQ workshop on Organization Theory and New Venture Creation, the 2012 Community of Social Innovation workshop, and the 2013 European Group on Organizational Studies Track 44. We also thank the Division of Research at Harvard Business School for funding to collect these data, and Peter Bracken and Stefan Dimitriadis for their excellent research assistance.
} 


\section{HOW THE ZEBRA GOT ITS STRIPES: IMPRINTING OF INDIVIDUALS AND HYBRID SOCIAL VENTURES}

The innovative social venture LendStreet Financial resembles two different types of organization at once. Founded by a former investment banker, it pursues its social mission of helping indebted people reduce their debts by delivering financial literacy programs and incentives that encourage responsible repayment. Yet prior to delivering these charitable programs to a new client, LendStreet purchases the client's debt from institutional investors. When the client increases their repayment rate as a result of the financial literacy and incentive programs, LendStreet, which now owns their debts, earns revenue which enables it to sustain its operations. LendStreet is an example of a hybrid organization (Battilana \& Dorado, 2010; Galaskiewicz \& Barringer, 2012; Pache \& Santos, forthcoming). It combines multiple existing institutional logics, which refer to the patterned goals considered legitimate within a given sector of activity, as well as the means by which they may be appropriately pursued (Friedland \& Alford, 1991; Suddaby \& Greenwood, 2005; Thornton, Ocasio, \& Lounsbury, 2012). Whereas profit-seeking organizations such as corporations follow a commercial logic and together constitute a commercial sector, organizations that pursue a social mission such as non-profits follow a social welfare logic and together constitute a social sector. Hybrid organizations such as LendStreet combine aspects of both, and therefore exist between institutionally-legitimate categories of organizations.

The creation of novel hybrid organizations seems to run counter to the core proposition of institutionalism that organizations tend to copy well-defined organizational forms in order to be regarded as legitimate (DiMaggio \& Powell, 1983). Although such organizational innovations reached through novel combinations of logics may occasionally be a source of breakthroughs, research also suggests that the survival of hybrid organizations is threatened by unique internal 
and external challenges (Jay, forthcoming). Initial studies of hybrids found that they indeed experience conflicting internal pressures between the logics that they combine, which may threaten their survival (Glynn, 2000; Heimer, 1999; Zilber, 2002). As objects that straddle multiple categories, hybrid organizations are prone to additional challenges relative to those embodying a single established form, due to their being more difficult to evaluate (Hsu, Koçak, \& Hannan, 2009; Zuckerman, 1999) and face multiple, potentially conflicting environmental demands (Greenwood, Raynard, Kodeih, Micelotta, \& Lounsbury, 2011; Pache \& Santos, 2010; Kraatz \& Block, 2008). Recently, studies have examined strategies that early-stage hybrid organizations use to preempt and reconcile incompatibilities between their multiple institutional logics (Jay, forthcoming; Pache \& Santos, forthcoming), with the shared conclusion that such strategies are difficult and not always successful (Tracey, Phillips, \& Jarvis, 2011).

Given the extraordinary challenges facing hybrid organizations, what can explain their creation? Organizational emergence is a central question in organization theory (Padgett \& Powell, 2011), yet research has not yet examined the factors that drive the creation of new hybrid organizations. In the entrepreneurial context, where nascent organizations already face general “liabilities of newness” (e.g. Stinchcombe 1965; Ruef 2005), hybrids, which are particularly prone to conflicts between their constituent logics and are difficult to recognize and evaluate, face additional challenges that make them especially likely to fail. Thus, explaining mechanisms that lead individual organizational founders to nonetheless combine logics, and thereby found a hybrid organization, promises to fill an important gap in organization theory.

Our approach to this question focuses on the role of environmental imprinting on individuals, which refers to the persistent effects that individuals' environments during sensitive periods have on their subsequent behaviors (for a review see Marquis \& Tilcsik, forthcoming). 
Past research has examined how past work experiences may influence individuals’ likelihood to become entrepreneurs, as well as shape their attention to existing entrepreneurial opportunities (Burton, Sørensen, \& Beckman, 2002; Shane, 2000; Sørensen, 2007). However, these studies have typically concluded that imprinting functions mainly as a mechanism of institutional reproduction and stability. By contrast, little is known about how imprints might lead to entrepreneurship that creates new types of organizations that diverge from institutionalized templates. In addition, few studies consider how individuals’ exposure to environments beyond their own direct work experience may produce imprints that influence their subsequent entrepreneurial behavior (Johnson, 2007).

Building on past studies that have examined how imprints in work settings influence subsequent work behavior (Higgins, 2005; Tilcsik, 2012; Dokko et al., 2009), we suggest that entrepreneurs' direct exposure to various work environments through their own experience influences their likelihood to create a new hybrid venture. In addition to this direct exposure, we propose that entrepreneurs' indirect exposure to work environments - through their parents' work experience and through professional education - also influences their likelihood to create a new hybrid venture. We explore these relationships in the context of early-stage social ventures that attempt to improve society. The founders of such ventures, often referred to as 'social entrepreneurs’ (Mair \& Marti, 2006; Short, Moss, \& Lumpkin, 2009), all enact a social welfare logic that guides the activities they undertake to benefit society. Some but not all of these ventures combine this social welfare logic with a commercial logic, leading to a hybrid venture like LendStreet (Galaskiewicz \& Barringer, 2012).

We predict that past exposure to commercial working environments imprints individuals with corresponding predispositions to commercial practices, thereby affecting their propensity to 
incorporate a commercial logic in their venture and create a hybrid social venture. More specifically, we first hypothesize that indirect commercial imprinting through parental work experiences and professional education increase the likelihood of founding a hybrid social venture. Second, we hypothesize that the effect of direct commercial imprinting through individuals' own work experience varies with their tenure in the commercial sector. We expect the direct imprinting effects leading to hybrid founding increase to be strongest during the early tenure of for-profit experience of an entrepreneur. However, as individuals spend longer periods of time working in for-profit businesses, we expect that their enactment of the commercial logic will become more automatic and rigid, leading them to be less likely to subsequently perceive that logic as compatible with the social welfare logic. As a result, as individuals' tenure in the commercial sector increases, the positive effect of direct commercial imprinting will diminish and individuals' likelihood of founding a hybrid will ultimately decrease.

To test our theory, we constructed a novel quantitative database of over 700 nascent social ventures from a combination of archival data and surveys containing items related to the entrepreneurs' individual life histories. Among these ventures, all enacted the social welfare logic but only some also enacted the commercial logic. Our analyses supported our hypotheses and thus suggest that indeed, individual imprinting helps to explain why an entrepreneur founding a social venture might create a hybrid by incorporating the secondary, commercial logic. In further, supplementary analyses, we explore the sensitivity of these commercial imprints to the presence of additional imprints that might have been acquired through exposure to social-welfare oriented environments. We find evidence that imprints acquired through indirect exposure versus direct exposure differ in these interactions, suggesting that whether 
imprints are acquired through direct or indirect means are a meaningful distinction, with consequences for how imprints affect subsequent behavior.

Our paper offers several contributions to understanding hybrid organizations, the factors that enable their emergence and organization theory generally. We contribute to the understanding of hybrid organizations by providing the first large-scale, empirical examination of the antecedents of the widely-discussed type of hybrids that combine social welfare and commercial logics (Battilana, Lee, Walker \& Dorsey, 2012; Haigh \& Hoffman, 2012). Addressing this issue is crucial to understanding why hybrids may emerge despite the legitimacy challenges that they face. These findings also contribute to institutional theory more generally by showing how environmental imprints on individuals may enable divergence from current, institutionalized structures, as well as how the contours of such imprints may vary with characteristics such as tenure and type of exposure. Finally, our study addresses repeated calls for deductive empirical research on social venturing and social entrepreneurs (P. Dacin, M. Dacin, \& Matear 2010; M. Dacin, P. Dacin, \& Tracey 2011), with the hope that this may help to organize and advance our understanding of the growing population of organizations that pursue social change.

\section{DISTINGUISHING BETWEEN TWO TYPES OF SOCIAL VENTURES: TRADITIONAL CHARITIES AND HYBRIDS}

The organizational population of "social ventures" consists of new, private organizations that deliberately attempt to improve society, and are distinct from both the state and business. Although they typically vary in the specifics of their social mission, e.g. poverty alleviation, social ventures all enact a social welfare logic that defines the legitimate goals of these 
organizations and the means by which they may be pursued; in other words, the social welfare logic is an organizing template for a distinct type of organizational activity that pursues social goals. According to this logic, social ventures are meant to create public goods that benefit society (Weisbrod, 1977). In order to do so, they are expected to allocate resources to activities that address their social mission (Moore, 2000).

All social ventures enact a social welfare logic, by definition. However, within social ventures, we argue that social ventures may be described in terms of two types (Weber, 1904), depending on the extent to which a secondary, commercial logic is also incorporated.

Historically, the dominant type of social venture is the traditional charity, which enacts the social welfare logic but not the commercial logic. Such social ventures constitute a "non-profit” sector or “third sector” distinct from business and government (DiMaggio \& Anheier, 1990; Hall, 2006). These organizations are situated within a resource niche that supported them, including professional social workers, charitable foundations and private donors. Furthermore, formal regulation emerged in many countries that legitimated and subsidized social ventures that pursued social goals, with the requirement that these ventures also not be used for personal profit (Hansmann, 1980). Such field-level developments ostensibly ensured the integrity of a field of charities engaging in work motivated by voluntarism and not by self-interest (Hall, 2006).

The second type of social venture is the hybrid social venture, which combines the social welfare logic with a commercial logic (Battilana, Lee, Walker, \& Dorsey, 2012). Despite the significant normative and regulatory boundaries delineating the not-for-profit sector from the commercial sector, an increasing number of new social ventures have recently taken this approach, in the process crossing the long-standing boundary between the two. Describing this trend, researchers note that these organizations depart from the traditional non-profit sector by 
engaging in "enterprising” practices normally associated with businesses (Light, 2008) and frequently entering into existing product and service markets (Young, 2009). As Galaskiewicz and Barringer (2012) argue of such organizations, they are "special, because [they] incorporate contradictory institutional logics into (their) mission and operations.” Many hybrid social ventures that combine social welfare and commercial logics sell goods and services in order to financially support their operations (Battilana et al., 2012; Foster \& Bradach, 2005).

The Centre for Vision in the Developing World (CVDW) and VisionSpring, two social ventures that aim to solve the social problem of poor eyesight in the developing world, illustrate the differences between traditional charity and hybrid social venture. The international development organization Centre for Vision in the Developing World (CVDW) is an example of a traditional charity that enacts the social welfare logic but not the commercial logic. The organization conducts research on, and produces, innovative eyeglasses that can be calibrated by the user, circumventing the need for professional optometry services that are typically not available in the developing world. These eyeglasses are distributed to individuals in developing countries and paid for by philanthropic donations. Consistent with the social welfare logic, traditional charities like CVDW that enact the social welfare logic pursue social goals and use volunteers, donors and other charitable resources, but do not employ markets or other commercial means.

Like CVDW, the organization VisionSpring also attempts to solve the problem of poor eyesight in developing countries. However, it combines the social welfare logic with the commercial logic (Bhattacharyya et al., 2010; London \& Christiansen, 2008), and is thus a hybrid social venture. Rather than fund and distribute the eyeglasses through philanthropy alone, VisionSpring has built a network of local entrepreneurs in the developing world that market and 
sell the eyeglasses in their own communities, providing a living wage for the entrepreneur while also funding the costs of development and production of the eyeglasses. Although it addresses the same problem as CVDW, it does so by engaging in a set of activities that combines the social welfare and commercial logics.

The creation of new hybrid social ventures like VisionSpring is not well-explained by dominant organization theories. Innovative entrepreneurial activity of all kinds is difficult to explain as rational choice (see Benz, 2009 for a review). Category-crossing in general carries a legitimacy deficit in the eyes of external evaluators and is consequently penalized (Hsu, Koçak,

\& Hannan, 2009; Zuckerman, 1999). In explaining why individual organizational founders might nonetheless combine logics to found a hybrid organization, we argue that imprints acquired through past exposure to certain work environments influence hybrid founding by shaping the availability of additional, culturally-accepted organizational templates and forms transposed from different fields as entrepreneurs construct new ventures (Giddens, 1984; Thornton et al., 2012). In the next section, we explore the nature of imprints of the commercially-oriented working environments to which social entrepreneurs have been exposed, and how these may influence their likelihood to create a hybrid social venture.

\section{IMPRINTING OF BUSINESS ENVIRONMENTS ON INDIVIDUAL ENTREPRENEURS}

Environmental imprinting refers to the effects that characteristics of individuals' environments during sensitive periods have on their subsequent behaviors (for a review see Marquis \& Tilcsik, forthcoming). Past research has described how in organizational work environments, individuals come to internalize a set of norms regarding how the work is to be performed (DiRenzo, 1977; Van Maanen \& E. H. Schein, 1979; Dokko et al., 2009), a process 
that Van Maanen and Schein (1979) describe as "the learning of a cultural perspective that can be brought to bear on both commonplace and unusual matters going on in the work place.” Such learning structures individual cognition in alignment with existing social structures, shaping individual dispositions toward their reproduction and reinforcement (Bourdieu 1977; Bourdieu \& Wacquant 1992). Individuals thus tend to re-enact the institutional logics that guided action in the past working environments in which they were socialized (Bourdieu, 1977; Emirbayer \& Johnson, 2008). In other words, they become imprinted with the institutional logics that were present in these working environments (Friedland \& Alford, 1991; Thornton et al., 2012). The imprinting mechanism is well-illustrated by Higgins' (2005) study of managers who spent their formative, early career years as junior managers at Baxter Pharmaceuticals, a fast-growing company that emphasized high levels of autonomy for early-career employees. Later, when these individuals created their own firms, they replicated the Baxter management philosophy to manage and coach their own employees.

To become imprinted by a particular environment, individuals may not need to experience that environment directly, but they instead may acquire indirect imprints through interaction with others who have been socialized by that environment. An environment may thus imprint individuals both through direct experience, and indirectly, through the "second-hand" impressions received by individuals from others with experience in the focal environment (Tilcsik, 2012). Accordingly, our approach examines how the various working environments in which individuals are both directly and indirectly socialized contribute to the cultural "tool kit" of logics that are available to them when formulating their new ventures (Swidler, 1986). Research on imprinting helped us to identify three key factors that are likely to have a lasting influence of individuals’ work behavior, namely parental work experiences, professional 
education and personal work experience (Marquis \& Tilcsik, forthcoming). Below, we analyze how each of these three sources of imprinting, both direct and indirect, may shape the range of logics available to entrepreneurs, and thereby, the type of social venture they create.

\section{Parental work experiences}

The social learning about organizations and work that occurs during childhood arises primarily through relationships in which the child shares a deep emotional bond, especially with the child's parents (Berger \& Luckmann, 1966). The family, and in particular the parents, operate as the child's initial reference group with respect to the social world; thus, the social roles and interactions observed in early childhood come to be seen as "normal" practices by which the child evaluates his or her own behaviors (Handel, Cahill, \& Elkin, 2007). The parent's experience at work therefore holds particular importance in the development of their child's understanding of work and organizations (Barling, Dupre, \& Hepburn, 1998). Deep, informal interactions take place in settings such as the family dinner table, where "family members talk about their experiences, and these are discussed, commented on, and evaluated... parents sometimes use the occasion as an instructional situation” (Handel et al., 2007: 138).

Although the nature of the interactions between parents and children vary between families, the nature of the imprints that children receive is partially determined by the vocations of the parents themselves. Research highlights how individual values associated with a parent's work influence the parenting styles by which they raise their children (Kohn \& Schooler, 1983; Kohn, Slomczynski, \& Schoenbach, 1986). Through these interactions, children often become imprinted with inclinations towards certain types of work that bear similarity to the work of their parents (Kohn et al., 1986; Miller \& Swanson, 1958). Similar patterns appear to apply to non- 
work, pro-social activities; individuals also tend to copy their parents’ participation in voluntary associations (Janoski \& Wilson, 1995; Mustillo, Wilson, \& Lynch, 2004).

Accordingly, we argue that the work experience of the parents of the founders of a social venture influences the type of social venture they will launch. Those whose parents had work experience in the for-profit sector will have experienced greater exposure to the commercial logic during their formative years and are therefore more likely to have its practices in their behavioral repertoire. As a result, founders of social ventures are more likely to found a hybrid that combines the social welfare and commercial logics when their parents have worked in the for-profit sector. Therefore, we hypothesize that:

Hypothesis 1: Social entrepreneurs who have a parent with for-profit work experience are more likely to incorporate a commercial logic in their ventures, resulting in a hybrid social venture.

\section{Education}

Formal education also provides a key medium by which logics may be transmitted to individuals. Through designed exposure of students to cultural models consistent with the environments in which they will subsequently work, formal education pre-socializes individuals for later organizational roles (Bowles \& Gintis, 2011). It is thus a key mechanism for the maintenance and reproduction of professions through the transmission of their underlying logics (Dunn \& Jones, 2010). The commercial logic, in particular, is embedded in a variety of professional business education programs that focus on such subjects as management, marketing, finance, or general business. In the $20^{\text {th }}$ century, the evolution of business education as a legitimate professional field resulted in rapid proliferation of such programs (Khurana 2008). 
We focus specifically on post-secondary business education for two reasons. First, this is the stage of education at which content frequently becomes specialized and its implicit, professional logics become salient. Second, post-secondary education is widely recognized as a unique and critical period in which students are particularly prone to educational influence (Evans, Forney, Guido, Patton, \& Renn, 2009). College and graduate school are environments deliberately designed to enable students to facilitate such relationships, and thereby de-construct and re-construct their values and identities (Jones \& Abes, 2004). Through interactions with teachers and peers who transmit professional values, post-secondary business education transmits knowledge that enables the socialized individuals to communicate and coordinate effectively within the field of business activity (Lacy, 1978; Trank \& Rynes, 2003). This knowledge includes taken-for-granted prescriptions about behavior in for-profit businesses that come to represent an appropriate repertoire of action. For instance, one in-depth field study of an elite business school found that "a central requirement of business school was that you learn to use the same language as everyone else... all business school courses addressed 'bottom line concerns, even a course called Management and Strategy, which argued for a holistic approach to management'.” (Schleef, 2006: 102, 109). In these ways, professional business education exposes students both formally and informally to widely-held, institutionalized templates for thinking about the world that aligned with the business world at large.

On this basis, we argue that business education is a key medium by which the commercial logic comes to be adopted by individuals. Social entrepreneurs who have experienced business education will thus be more likely to incorporate the commercial logic in their ventures. 
Hypothesis 2: Social entrepreneurs who have participated in formal post-secondary business education are more likely to incorporate a commercial logic in their ventures, resulting in a hybrid social venture.

\section{Personal work experiences}

Upon entering adulthood, individuals themselves typically join work environments that shape their orientations and behavior. Research on adult work socialization has focused primarily on individual entry into organizations, with an emphasis on consequences for those individuals' behavior during their organizational tenure (Bauer, Morrison, \& Callister, 1998; Chao, O’LearyKelly, Wolf, Klein, \& Gardner, 1994; Feldman, 1981; Van Maanen \& E. H. Schein, 1979; Saks \& Ashforth, 1997). As individuals enter into new organizations, they learn the behaviors and values that are seen as legitimate in those organizations (DiRenzo, 1977); effective socialization thus enables successful role performance.

Organizational environments may also imprint individuals in ways that influence their behavior at a later time, including after they leave the socializing organization (Kacperczyk, 2009; Tilcsik, 2012). Past research has found that imprints acquired in this way may influence several dispositional dimensions related to organizational founding, including individuals' managerial style (Higgins, 2005), appetite for entrepreneurial risk-taking (Kacperczyk, 2009), and templates for applying knowledge (Azoulay, Liu, \& Stuart, 2009). Imprinting also shapes potential entrepreneurs' attention to opportunities and information (Eckhardt \& Shane, 2003; Shane, 2000; Burton, Sørenson \& Beckman, 2002). In one study of a single 3-dimensional printing technology, Shane (2000) documented eight vastly different applications of the same basic technology. Each proposed venture drew directly on the unique templates and knowledge 
acquired in founder's previous profession. Building on this research, we propose that among entrepreneurs who create social ventures, those who have been imprinted with the commercial logic through first-hand professional experience in for-profit organizations will be more likely to incorporate a commercial logic in their social ventures.

However, we also expect that the positive, marginal imprinting effects of experience in for-profit sector on incorporating the commercial logic will decrease with increased tenure in the imprinting organization, and may even become negative over time. Evidence suggests that although powerful, the imprinting effects of socializing experiences are neither linear nor monotonic (Tilcsik, 2012). Phillips' (2000) study of law firm founding found that new firms founded by senior partners in existing firms were less likely to survive than those founded by those with less experience, suggesting some difference in the imprinting of routines that takes place in early versus later years. We argue that longer tenure within a particular organizational type may actually impede the effective incorporation of different logics into new ventures because of the over-accumulation of habits, beliefs and other "baggage" that is not consistent with the tasks or environment of the new venture (Dokko et al., 2009). In other words, extended experiences contribute to cognitive rigidities that lead to automatic, non-reflective behavior. We expect longer tenure to therefore limit entrepreneurs' capability to creatively re-apply their commercial experience to their social ventures, and thus to make them less likely to combine logics in a hybrid form.

To summarize, short tenure in for-profit employment should be associated with a more flexible enactment of a secondary commercial logic, allowing the entrepreneur greater discretion to combine logics without perceived conflict. As individuals acquire deeper for-profit employment, we expect that this additional "baggage" will be associated with the perception of a 
more closely circumscribed range of possible actions, leaving less discretion to cross boundaries and create a hybrid venture. Building on these arguments, we predict that the existence of some for-profit work experience in an entrepreneur's past will have a positive effect on the likelihood that they will incorporate a commercial organizational logic in their social venture. However, we also predict that these imprinting effects will diminish over time.

Hypothesis 3: Social entrepreneurs' likelihood of incorporating a commercial logic in their social venture and thereby founding a hybrid social venture will increase with a small amount of work tenure in a for-profit business, but the marginal effects of greater for-profit tenure will diminish and ultimately decrease, resulting in a an inverted Ushaped ( $\cap$ ) relationship.

\section{METHODS}

\section{Sample}

To construct our sample of social ventures, we began by contacting a non-profit organization that conducts an annual fellowship competition for entrepreneurs who launch social ventures. This fellowship-granting organization is among the most prominent early-stage funders of social entrepreneurs. Winners of the competition receive funding to pay the entrepreneur's living costs while he or she works on their venture. The rules of this fellowship competition stipulate that ventures must be in the idea phase or early-stage, not to exceed two years of operations, and that they must pursue "positive social change" without constraints on the activities or strategies of the venture; all applicants must furthermore confirm that their venture was their "original idea". Among similar programs that support the founders of early stage social 
ventures, this one has the least restrictive criteria for the types of individuals and ventures that may apply.

To avoid selection bias, we considered the full population of entrepreneurs who applied for the fellowship, irrespective of their success in the fellowship competition. The organizations in our sample are in a stage of nascent entrepreneurship, defined as serious activities that are intended to culminate in a viable startup (Aldrich \& Martinez, 2001; Reynolds \& White, 1997). The stage of development of the entrepreneurs in our sample allows us to address oft-cited criticisms of entrepreneurship samples that contain survivorship bias (Katz \& Gartner, 1988). For every applicant to the fellowship in two consecutive application cycles (2011 and 2012), we made contact by email shortly following their applications, and invited them to participate in a survey. Prior to the survey administration, we pre-tested the questions on other social entrepreneurs who had applied in an earlier year to test for comprehension and correspondence to the underlying constructs, and altered the survey to improve comprehension. All applicants received a web-based survey instrument containing questions related to their personal backgrounds and to their social ventures. The response was 1,816 total entrepreneurs and their ventures, or 26 percent. This response rate is consistent with those of other published studies using a similar methodology and met our expectations for this research design, considering in particular the need for the direct involvement of the entrepreneur and the personal nature of the information provided (Alpar \& Spitzer, 1989; Coviello \& Jones, 2004).

Following the administration of the survey, we constructed archival data on the respondents from the original application materials related to topics such as gender, age, and geographic location, and matched these data to the survey responses. These descriptions were typically 1,000-1,500 words in length. They were all structured as responses to specific questions 
about topics that included the social mission of the venture, its most innovative characteristics, and intended sources of financial and other resources. We also acquired the personal curricula vitae of each social entrepreneur and their descriptions of the venture projects produced by each applicant to the fellowship. In order to test for survey response bias in the types of projects proposed, we investigated the distribution of ventures by program area, a variable based on applicants' self-categorization into one of seven issue areas (including Arts and Culture, Civil and Human Rights, Economic Development, Education, Environment, Health/Healthcare, Public Service) corresponding to the social issue they intended to address. To measure the goodness of fit on this variable between survey respondents and the full sample, we computed a Pearson chisquare statistic of 8.69 , below the $\mathrm{p}=.05$ cut-off criterion of 12.59 , suggesting that the distribution of project types among survey respondents did not differ significantly from the full population of applicants based on this categorization of project types. As an additional test for possible survey response bias in terms of applicant characteristics, we compared our sample of survey respondents to all applicants on age and gender and found only small differences (sample means $($ age $=36.4$, male $=0.55)$; population means $($ age $=35.7$, male $=0.56)$.

While the vast majority of the applicants applied alone, some of them (less than $24 \%$ in our sample of survey respondents) applied in two-person partnership. Consultation with the fellowship-granting organization suggested that in applications from two-person partnerships, the first partner was typically the dominant partner in formulating the venture, and so we discarded responses received from individuals listed as the $2^{\text {nd }}$ partners. In robustness checks reported later in the results section, we find that results hold when holding these responses in the sample, as well as when dropping all responses from those who applied with a partner. We similarly discarded responses from those applicants for which the unavailability of archival data needed 
for the creation of our independent variables, such as curricula vitae, were unavailable. Finally, we included for the purposes of our analysis only those applications for which the organization had already attained legal recognition by the government. Existence of the organization as a legal entity provides a minimum threshold for organizational initiation and thus is a relatively conservative criterion for including only ventures that have initiated meaningful organizational activity. Our resulting, final sample included 708 entrepreneurs and their social ventures.

As noted above, the fellowship competition solicited applications specifically from social ventures that pursued positive social change. However, in order to validate that the ventures identified through this source were all actually social ventures pursuing a social mission, we coded the project descriptions collected through their applications. Two independent coders coded project descriptions for a random sample of $40 \%$ of the applications in the first application cycle in order to identify who benefited from the activities of the venture. Together with our coding team, a list of beneficiary groups was developed, then refined based on the judgments of the coders (a full list of these beneficiary groups and frequencies is provided in Table 1). All projects were separately coded by the two coders, then compared and discussed when there was disagreement. The results indicate that every venture served at least one of the identified beneficiary groups, suggesting that our sample may reasonably be assumed to constitute a sample of social ventures.

Insert Table 1 about here

\section{Dependent Variable}

Hybrid social venture. To identify the social entrepreneurs in our sample who incorporated a commercial logic in their ventures, thereby creating a hybrid social enterprise, we 
developed quantitative measures of the extent to which they were guided respectively by the social welfare and commercial logics. Building on past research that measures the extent to which a logic is enacted in new ventures (Cliff, Jennings, \& Greenwood, 2006), we constructed separate measures of the extent to which the social welfare and commercial logics were enacted, resulting in two series of 5-point, Likert-style items that captured the scholarly view of the commercial and social welfare logics, respectively. A score for each logic was calculated as the unweighted sum of these items. Because hybridity is conceptualized as the combination of multiple logics, the hybrid social venture variable, which we present in more detail below, was calculated as the product of the scores for each of the two logics.

Our approach to scoring ventures in terms of each of the two logics began with the idea that institutional logics can be characterized in terms of two parts: the legitimate goals that they prescribe, and the appropriate means by which they are to be pursued (Dobbin, 1994; Pache \& Santos, 2010; Scott, 1987, 1994). To capture the goal aspect of the logics enacted by each entrepreneur, we developed two five-point, Likert-style items that respectively corresponded to the commercial and social welfare logics. To measure the goal aspect of the social welfare logic, we asked respondents to what extent "my venture addresses an opportunity to positively impact society," while to measure the goal aspect of the commercial logic we asked to what extent "my venture addresses an opportunity to make money.”

Regarding the means of pursuit, entrepreneurship research has long focused on resources and resource mobilization as the focus of nascent entrepreneurial activity (Aldrich \& Zimmer, 1986; Shane \& Venkataraman, 2000). The combination of resources embedded in multiple sectors is distinctive to hybrid organization (Battilana \& Dorado, 2010; Jay, forthcoming; Pache \& Santos, forthcoming). We therefore formulated our items describing means in terms of five 
different categories of resource providers with which the nascent venture engages, and which our pilot tests indicated were meaningful to the entrepreneurs: funders, employees, partners, customers, and the entrepreneur himself or herself. We then developed two five-point, Likertstyle items respectively corresponding to each of the two logics for each resource provider (see Appendix A for a full list of these items). Our measures of the extent to which the social entrepreneurs in our sample were guided respectively by the social welfare and commercial logics were therefore each calculated as the sum of six items, one corresponding to goals and five corresponding to means.

In order to verify that our items captured the underlying logics, we conducted checks at various stages of the research process. Prior to distributing the survey, we conducted a series of discussions with social entrepreneurs and other experts to verify the alignment of these items with the underlying logics present in the environment. To maximize the likelihood that our items would be meaningful to our respondents, we also piloted them as part of a separate survey to several hundred more mature entrepreneurs and their ventures to ensure that the items were clear and corresponded to their underlying theoretical constructs.

We also conducted factor analyses in order to test whether our items captured the underlying logics. Following the implementation of the survey, we conducted an exploratory factor analysis that estimated the loadings of each of the six items on underlying factors that captured the commercial and social welfare logics, respectively (see Table 4). As expected, this produced two factors with eigenvalues exceeding one, the typical cutoff criterion (Gorsuch, 1997). Both factors had high alphas (alpha $=.74$ for the social welfare factor, and alpha $=.88$ for the commercial factor), indicating an acceptable level of inter-item correlation (Nunnally, 1978). Exploratory factor analysis is generally accepted as a method for inductively establishing the 
underlying qualities of factors and their relationship to multiple indicators; however, because the survey items were developed ex ante prior to the creation of the factors, we additionally conducted a confirmatory factor analysis to deductively test the correspondence of our survey items to the two factors. We used standard structural equation modeling techniques, leaving the loadings on each indicator unconstrained. This analysis resulted in an identical assignment of the twelve indicators to two factors corresponding to the commercial and social welfare logics, with a comparative fit index (CFI) of 0.92. Studies employing SEM conventionally assess CFI using a cutoff of .90 (Bentler \& Bonett, 1980), suggesting that our assignment of items to the two logics was valid.

\section{Independent Variables}

Parents' for-profit work experience. To measure the past work experience of the entrepreneur's parents, we asked entrepreneurs to report, for each of their parents, whether that parent had been employed in a for-profit organization. In cases that parents were not the respondent's primary caretakers, the question specified that respondents should answer regarding their primary caretakers instead. Accordingly, we measured parents' for-profit experience with a dummy variable coded as 1 for entrepreneurs who had at least one parent (or primary caretaker when applicable) who worked in the for-profit sector and coded as 0 otherwise.

Business education. To identify whether individual entrepreneurs had experienced formal business education, we coded their education experience from their curricula vitae. We manually transcribed the major field of each entrepreneur's formal education experiences, then an independent coder categorized these according the scheme of 32 education fields used by the U.S. National Center for Education Statistics (Snyder \& Dillow, 2012). One of these 32 fields is 
"Business,” which in our coding encompassed a range of subfields such as "Accounting," “Finance,” “General Management,” and “Marketing”. Accordingly, we captured entrepreneurs' business education with a dummy variable coded as 1 for entrepreneurs who had at least one such formal education experience in business and coded as 0 otherwise.

Own for-profit work experience. To measure the past work experience of entrepreneurs, we asked respondents to report their years of work experience in the category "worked in a forprofit organization”. This is consistent with past studies that have successfully used survey approaches to collect information on length of past employment (Astebro \& Thompson, 2011). Accordingly, we measured tenure in the for-profit sector as the total number of years of work experience in this sector.

\section{Control variables}

Past research has indicated that age is a strong predictor of entrepreneurial behavior, perhaps due to differences in entrepreneurs' expectations for how many future productive years they will be able to work on the ventures (Parker, 2004). Because the prominence of social venturing has changed substantially during the lifetimes of the entrepreneurs in our sample, the inclusion of age also provides a control for generational effects related to the cultural acceptance of these ideas. Research also suggests that gender may explain some variation in the likelihood of individuals to employ commercial activities. In particular, business management is instead culturally viewed as a naturally male activity, independent of individuals' objective competencies (Schein, 2001). Although research identifies a gradual redefinition of gender schema over time with respect to work and family demands, prevailing schema of gender and 
work still prescribe that females work in the home and in non-commercial activities (Haveman \& Beresford, 2012).

In addition to our hypotheses about imprinting through education, an individual's level of prior education has been linked to a variety of entrepreneurial outcomes (Davidsson \& Honig, 2003; Van der Sluis, Van Praag, \& Vijverberg, 2008). For this reason, we used data from the founders' fellowship applications to create indicator variables corresponding to their highest level of education in six categories (Some Primary or Secondary School, Secondary School Graduate, Some College, Associate’s Degree, Bachelor’s Degree, Graduate Degree). To control for inter-sectoral variation in the extent to which hybrid models are legitimate, we created indicator variables based on the entrepreneur's self-categorization into one of 7 program areas (including Arts and Culture, Civil and Human Rights, Economic Development, Education, Environment, Health/Healthcare, and Public Service) corresponding to the social issue they intended to address. Finally, because our sample was drawn from data collected at two different times, we included an indicator variable called Applied in 2011 to control for any possible temporal differences between these two groups. The latter 3 variables were all collected from the entrepreneurs’ archived fellowship applications.

Although the ventures in our sample already meet relatively narrow criteria to validate their nascent stage of development, we also attempted to control for any systematic changes that may have occurred between the earliest instance of opportunity identification and the administration of our survey. We addressed such differences by controlling for the number of key milestones completed. Ruef's (2005) process theory of organizational founding identifies five key stages: initiation, resource mobilization, legal establishment, social organization, and operational startup. To proxy for these stages, we asked survey respondents to report whether 
they had reached several milestones: the full-time self-employment of the entrepreneur working on the venture, receipt of funding, legal establishment, hiring of an employee, and initial delivery of product or services. Our control for milestones completed was then calculated as the count of these milestones the entrepreneur reported having already reached. Since all of the ventures in our sample had reached the stage of legal establishment, this variable had a minimum value of 1 and a maximum value of 5. For example, a founder who was full-time employed on the venture, had received external funding, and had legally registered the venture, but had not hired an employee nor delivered any products or services was assigned a value of 3 for this variable.

\section{Analyses}

We formalized the process by which socialization experiences resulted in the creation of hybrid social ventures using an OLS linear regression model, with hybrid social venture as the dependent variable. The majority of our independent variables are not correlated with each other or with our controls (see Table 2), suggesting that multicollinearity is unlikely. However, due to the presence of the quadratic term for personal work experience and some high individual correlations, we also calculated regression diagnostics and found that the Variance Inflation Factor for all of the independent variables in our models was less than 10, the recommended maximum threshold (Gujarati, 2003).

\section{RESULTS}

Table 2 presents the correlations and descriptive statistics for our variables and Table 3 presents the results of our analyses. Model 1 estimates the baseline coefficients of our control variables. Model 2 estimates the effect of parental for-profit work experience. Model 3 estimates the effect of professional business education. Models 4 and 5 estimate the effects of workplace 
socialization. Model 4 estimates the linear effect of work tenure in for-profit organizations, while Model 5 decomposes this mechanism into linear and exponential effects to measure the concavity of this relationship. Model 6 is a full specification including all of the aforementioned variables.

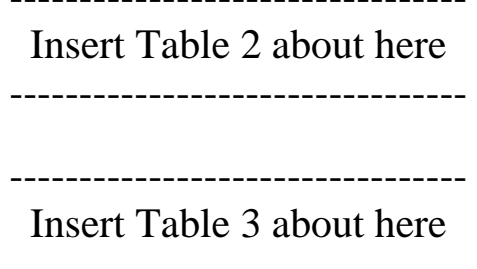

Our analyses found support for each of our three hypotheses. Model 2 estimates a positive and significant coefficient on parental for-profit work experience, providing support for Hypothesis 1, which states that the likelihood of an entrepreneur incorporating a commercial logic in their social venture increases when a parent has had for-profit work experience. Model 3 estimates a positive and significant coefficient on professional business education, supporting Hypothesis 2. Model 4 estimates a positive and significant coefficient on the number of years of the entrepreneur's own for-profit work experience. Model 5, which includes linear and quadratic terms, estimates a positive coefficient on the linear term but a negative coefficient on the quadratic term. This suggests that an entrepreneur's likelihood of incorporating a commercial logic increases with their past socialization in for-profit organizations, but that this effect diminishes and becomes more negative over time, providing support for the negative U-shaped relationship described in Hypothesis 3. Interpreting these results numerically, the average predicted hybridity peaks after approximately 22 years of for-profit work experience, after which it decreases. Model 6 finds that the coefficients in the full specification of the model remain directionally consistent and significant. 
Regarding the control variables, as expected, men were more likely than women to incorporate a commercial logic in their venture, thereby creating a hybrid social venture. The results furthermore suggest some significant differences in the likelihood of founding a hybrid between program areas: economic development and environment were areas in which social ventures were significantly more likely to incorporate the commercial logic. The overrepresentation of hybrid ventures in these categories suggests the possible existence of fieldlevel differences that influence the combination of social welfare and commercial logics, a topic we return to in the discussion.

\section{Robustness checks}

As a robustness check of our analysis, we constructed an alternative measure of our dependent variable that treated hybridity as a binary construct. Specifically, for each logic, we took an average of the underlying 5-point constructs that we presented above. For each of the social welfare and commercial logics, each venture was coded as " 1 ” if the average was at least 4 out of 5 , and was coded as “ 0 ” otherwise. When ventures were coded as a " 1 ” for both logics, they were coded as hybrid social ventures. We then re-ran the same models to test our three hypotheses, using logistic models to account for the binary form of our new dependent variable. Results are reported in Table 4. We find that all three of our hypotheses were still supported in this modified specification of the dependent variable and corresponding functional form.

Insert Table 4 about here

Also, despite strong evidence suggesting that our respondents acted as the primary founders who initially formulated the venture, we additionally re-ran our analyses on a restricted sample that excluded entrepreneurs who applied for the fellowship along with a partner. We 
found significant support for all three of our hypotheses. Finally, we conducted a set of additional robustness checks to explore the sensitivity of our findings to the entrepreneur's current resource environment. We recognize that the entrepreneur's current resource environment, including the financial resources under his or her control, also plays a significant role in the nature of the opportunities he or she may recognize or pursue (Shane, 2003). To test whether financial resources were confounding, we built secondary models testing for a main effect of the founder's current family income using the same setup as our main models, and found no significant effects. We did not include this as a control in the main model due to significant missing data, but our secondary tests suggest that financial resources did not account for significant omitted variable bias.

\section{Supplementary analysis: Examining the effects of additional imprints}

Our hypotheses and research design examined how entrepreneurs that enact one logic (in this context, the social welfare logic) might be influenced by past direct and indirect commercial imprints to incorporate a second logic (in this context, the commercial logic) and thereby found a hybrid venture. In supplementary analyses, we sought to examine whether the imprinting effects hypothesized in $\mathrm{H} 1, \mathrm{H} 2$ and $\mathrm{H} 3$ were sensitive to the presence of additional imprints. The specific additional imprinted logic we focused on is the social welfare logic that is dominant in the context of social venturing. In other words, we examine how the presence of an additional, social welfare imprint may influence the effect of the commercial imprint on the likelihood that the commercial logic will be incorporated, thus creating a hybrid social venture. Consideration of this intersection thus allowed us to interpret in a more nuanced way the dynamics of the commercial imprints investigated in our main analyses. 
To test the effects of the additional imprint, we estimated OLS models using our original, continuous dependent variable that test again our initial three hypotheses, this time including two additional terms: (1) a term that captures imprinting by the social welfare logic, and (2) an interaction term that captures whether the entrepreneur experienced socialization in both the commercial and social welfare logics. For Hypothesis 1, the measure of the social welfare imprint was a binary variable that was equal to " 1 " if any parent had worked in a non-profit, and "0" otherwise. For Hypothesis 2, we used a binary variable that was equal to "1" if the entrepreneur had formal education in the "public administration and social services" field. Finally, for Hypothesis 3, we used years of work experience in non-profit organizations. For each hypothesis, these variables were gathered using the same procedure used to measure the commercial imprint. In Table 4, Models 2-3 correspond to Hypothesis 1, Models 4-5 correspond to Hypothesis 2, and Models 6-9 correspond to Hypothesis 3.

Insert Table 5 about here

Our results indicated that the presence of the social welfare imprint influenced the effects of commercial imprints in different ways. For parental imprinting, we find no significant effect of the social welfare imprint on the likelihood of hybrid founding, as expected (Model 2), but find a negative and weakly significant effect of the interaction between the commercial and social welfare imprints (Model 3). For educational imprinting, we find a significant negative effect of education associated with the social welfare imprint (Model 4), and again find a weakly significant, negative effect of the interaction between the commercial and social welfare imprints (Model 5). Finally, for imprinting through individuals’ own work experience, we find no significant effect of the social welfare imprint on the likelihood of hybrid founding (Model 6). 
However, our models estimate a weakly significant positive effect of the interaction between non-profit work experience and for-profit work experience (Model 7), on both the linear and quadratic terms. In summary, the findings suggest that additional, social welfare imprinting weakens the effects of commercial imprinting for parental and educational experiences, but strengthens the effect of commercial imprinting that arises from the entrepreneur's own work experience.

\section{DISCUSSION}

In this study, we explored the antecedents of hybrid organizations by studying how individual imprinting by business-oriented environments leads founders of social ventures to combine a social welfare logic with a commercial logic, thereby creating a hybrid social venture. We find effects on hybrid founding by commercial imprints from three sources: the founder's parents, post-secondary education, and his or her own work experience. The results also suggest that the effect of the commercial imprints acquired through the founder's own business experience diminishes and may even become negative with extended tenure of the individual in the business environment.

In supplementary analyses, we investigated the sensitivity of commercial imprint to the presence of additional, social welfare imprint. We found that whereas the additional, social welfare imprint strengthened the effect of the commercial imprint acquired through the founder's own work experience, it weakened the effects of commercial imprints acquired through one's parents or post-secondary education. These findings point to an important distinction between sources of environmental imprinting by which institutional logics may be transmitted. The combination of both symbolic content and material practice has been described as a critical 
feature of the institutional logics perspective (Friedland \& Alford, 1991; Thornton et al., 2012), in contrast to earlier institutional accounts that have been criticized for over-emphasizing the symbolic aspects of institutions (Tolbert \& Zucker, 1996). One interpretation of our findings with respect to additional imprinting draws on this distinction between symbols and material practice in the way that logics are transmitted to individuals. In the main findings, the commercial logic was imprinted irrespective of whether it was transmitted to the entrepreneur primarily through indirect, symbolic means (i.e. by parents or formal education), or also through both symbolic and material practice (i.e. through the direct work experience of the entrepreneur). Both positively influenced the likelihood that the commercial logic would be incorporated into the social venture. However, our supplementary analyses suggest that additional imprinting with the social welfare logic strengthened the imprint of the commercial logic in the case of direct imprinting, but weakened the imprint of the commercial logic in the case of indirect imprinting.

Although these findings are limited to the influence of social welfare imprints on commercial imprints, they suggest that imprints acquired through primarily symbolic experience may confer to the individuals a more limited facility with their associated logics than those that acquired directly, through both symbolic and material practices. When the entrepreneur experiences a "thick" imprint through the direct practice of work experience, it enhances his or her ability to enact it simultaneously with other logics; thus, direct imprinting with the social welfare logic increases the likelihood that the commercial logic can be incorporated when the entrepreneurs had also been imprinted by the commercial logic. However, when the social imprint additional imprint is transmitted only indirectly, and is therefore relatively more "thin", it does not confer the same capacity to combine logics. In fact, we found evidence that in the latter case, the additional social welfare imprint may negatively affect the influence of the commercial 
imprint on the creation of a hybrid venture. One interpretation of this finding is that when individuals experience multiple logics only through their symbolic content, not only may they not gain the capacity to combine them, but they may be more attuned to potential incompatibilities.

\section{Contributions}

Long-standing theoretical models in institutional theory suggest that the creation of organizational forms that are not well-defined and cross categories is counter-intuitive, and perhaps even foolish (Aldrich \& Fiol, 1994). Yet the recombination of existing organizational templates is a key source of institutional innovation (Haveman \& Rao, 2006; Padgett \& Powell, 2011). Among entrepreneurs pursuing social ventures, organizational innovation of this type appears to be growing in frequency (Battilana et al., 2012). We study these social ventures and the entrepreneurs who create them in order to test the role of past environmental imprints as antecedents of organizational hybridity. By focusing on how parental, educational and direct work imprinting facilitates emergence, we attempt to show conditions that enable hybrid entrepreneurship in spite of immediate environmental pressures that inhibit it.

By focusing specifically on hybrid social ventures, we contribute to the literature on social enterprise and social entrepreneurship. Research in organizational theory has long investigated the functioning of organizations in the for-profit and the not-for-profit sectors, but has paid scant attention to hybrid social ventures that straddle the for-profit and not-for-profit categories (Galaskiewicz \& Barringer, 2012). Scholars who have studied both sectors have so far focused on comparing and contrasting their functioning (Ben-Ner, 2002; DiMaggio \& Anheier, 1990; Hansmann, 1987; Rushing, 1974). These comparisons have led to a growing reflection not 
only about what not-for-profit organizations can learn from corporations (Dart, 2004; Dees \& Anderson, 2003; Dees, 1998; Eikenberry \& Kluver, 2004; Foster \& Bradach, 2005) but also what corporations can learn from not-for-profit organizations (Austin, 2000; Drucker, 1989). Recent studies have started examining how organizations can sustainably hybridize the commercial and social welfare logics (Battilana \& Dorado, 2010; Pache \& Santos, forthcoming; Jay, forthcoming). However, ours is the first empirical test of the influences that lead to the founding of hybrid social ventures and one of the largest empirical studies of social enterprises and their founders to date.

The results of our study also point to the importance of the individual level of analysis in explaining the emergence of hybrid organizations and institutional innovation generally, a finding in line with recent research that shows how individual effects can influence behavior against institutionalized categories (Jay, forthcoming). Far from adopting a reductionist approach that would not account for the influence of the environment on individuals' behaviors, we theorize, and we find evidence, that past imprints shape subsequent entrepreneurship, suggesting a broader role for individuals, particularly individual entrepreneurs, in institutional dynamics. A focus on individuals' role in institutional change has roots in early organization theory and old institutionalism (March \& Simon, 1958; Selznick, 1947), but it has since then been neglected (Besharov \& Khurana, 2012; Selznick, 1996). In particular, the idea that individuals 'carry' logics through their life histories is widely assumed, but under-theorized.

While there have been many recent calls for research accounting for the role of individual-level processes both in institutional change and maintenance (Powell \& Colyvas, 2009; Battilana et al., 2009), very few institutional studies have accounted for how individuals' past socialization may function to maintain or disrupt social structures over time (Tilcsik, 2010). 
Taken together our findings suggest that institutional change cannot be fully understood at the field or even the organizational level alone. Rather, it must acknowledge the way in which individual actors, who are themselves mobile across established fields (Bidwell \& Briscoe, 2010), receive and enact their institutional "tool kit". One interpretation of the findings in our study is that the effects of socialization experiences on behavior are mediated by individual entrepreneurs' habitus, the temporally durable principles of judgment and practice acquired by individual agents through their life experiences (Bourdieu, 1977). As such, it provides empirical support for the role of individual entrepreneurs' habitus in their choices and behaviors. We are hopeful that the multi-level nature of the institutional logics perspective that we explored in our study enables a greater incorporation of individuals into theories of institutional maintenance and change (Thornton et al., 2012).

Finally, our study contributes to understanding how multiple imprinting may influence entrepreneurial action. While studies of individual imprinting typically focus on aspects of a single, coherent environment, a more realistic model of individual development considers multiple experiences, and indeed, the intersection of these multiple imprints. The supplemental findings of this study provide one of the first tests of how multiple imprints may enable the hybridization of multiple institutional logics in a single, novel venture. The findings suggest that this type of divergence is enabled by multiple imprinting, but only when socialization arises from direct experience, and not through mere exposure, via second-hand, indirect social interactions. This highlights important variation in the imprints acquired from different sources, a type of variation which has been little-studied to date, but which we believe carries significant promise for future research.

\section{Limitations and future research directions}


Although the setting of our study is particularly interesting as it enables us to study novel forms of hybrids that are on the rise, it places limitations on the interpretation of the findings. Our empirical population corresponds to a population of entrepreneurs who all enact a social welfare logic. Social ventures provide a relevant setting within which we can test our model, but limits inferences about the mechanisms leading to the founding of hybrids in entrepreneurial populations beyond this domain. Because this domain contains meaningful variations on only one of the two logics, we were only able to study the imprinting of the commercial dimension conditional on the enactment of the social welfare logic. We believe it is reasonable to expect that our findings related to the role of imprinting will apply more broadly, including beyond the context of social ventures, but our results should nonetheless be interpreted as conditional on the characteristics of our sample.

Second, we are aware of possible endogeneity concerns related to some of our independent variables. Although imprinting experiences associated with the commercial logic are positively correlated, our results still hold in the full specification of the models, suggesting that despite their correlation, each socialization experience still has significant independent effects on the likelihood of hybrid founding. We wish to make clear, however, that our models did not attempt to comprehensively map the socialization process of any individual's life history, but had the more modest goal of identifying average effects of key imprinting experiences in an individual's history on the nature of the ventures they later create.

Future research may examine other factors that may influence the emergence of hybrids. Such research could extend beyond the individual level to address the role of social influence. Our setting was not well-suited to the generation of network data; however, a natural proposition to test with such data in the future would be whether hybridization follows from multiple 
embeddedness (Seo \& Creed, 2002). At the field level, the findings of our study hinted that social ventures created in certain industries were more likely overall to be hybrid. In our control variables, the two program areas where social ventures were significantly more likely to incorporate a commercial logic - economic development and the environment - roughly correspond to areas of activity in which markets already exist. Our findings would suggest that certain field-level factors may influence the extent to which the commercial logic and social welfare logic may be combined. Additional field-level factors such as the maturity of organizational fields, interactions with other fields, and the precedent of prior hybridization all may influence the combination of logics and emergence of hybrid organizations, making this an important next step for this line of research (Chen \& O’Mahony, 2006).

Another key area for future research is the performance of hybrid social ventures, and what material and institutional conditions are necessary for them to succeed. As hybrids that combine social and financial goals become more prevalent, we would expect to observe the emergence of a field that functionally and institutionally organizes this activity. Research hints at the mechanisms by which such field-building might take place (Maguire, Hardy, \& Lawrence, 2004; Tracey et al., 2011), but still little is understood about how the presence of multiple, potentially incompatible logics will affect this process. Past research has found that one cause of the more general "rationalization" of the non-profit sector is the mobility of professionals from the business sector into established non-profit organizations, into which they import the business practices with which they are familiar (Hwang \& Powell, 2009). However, research examining how commercial practices might become incorporated into new ventures is only nascent (Pache \& Santos, forthcoming).

\section{Conclusion}


The creation of hybrid organizations that combine existing organizational forms is a complex, multi-level process. Beyond showing how individuals and imprinting may lead to the creation of new hybrids, we hope that this study contributes to the development of the emerging body of research on hybrid organizations. In the present period of foment and experimentation at the boundaries of the social welfare and commercial logics, further investigation of organizational hybridity will not only contribute to better understanding the efforts of individual entrepreneurs and the ventures they create, but will also enrich our understanding of broader processes of institutional innovation and change. 


\section{References}

Aldrich, H. E, \& Martinez, M. A. 2001. Many are called, but few are chosen: An evolutionary perspective for the study of entrepreneurship. Entrepreneurship: Theory and Practice, 25(4): 41-57.

Aldrich, H.E., \& Fiol, C. 1994. Fools rush in? The institutional context of industry creation. Academy of Management Review, 19(4): 645-670.

Aldrich, H.E., \& Zimmer, C. 1986. Entrepreneurship through social networks. In D. Sexton \& R. Smilor (Eds.). The art and science of entrepreneurship, 3-23. Cambridge, MA: Ballinger.

Alpar, P., \& Spitzer, D. 1989. Response behavior of entrepreneurs in a mail survey. Entrepreneurship Theory and Practice, 14(2): 31-44.

Åstebro, T., \& Thompson, P. 2011. Entrepreneurs, jacks of all trades or hobos? Research Policy, 40(5): 637-649.

Austin, J. E. 2000. Strategic collaboration between nonprofits and business. Nonprofit and Voluntary Sector Quarterly, 29: 69-97.

Azoulay, P., Liu, C. C., \& Stuart, T. E. 2009. Social Influence Given (Partially) Deliberate Matching: Career Imprints in the Creation of Academic Entrepreneurs. Working paper. Harvard Business School.

Barling, J., Dupre, K. E., \& Hepburn, C. G. 1998. Effects of parents’ job insecurity on children’s work beliefs and attitudes. Journal of Applied Psychology, 83(1): 112.

Battilana, J., Leca, B., \& Boxenbaum, E. 2009. How actors change institutions: towards a theory of institutional entrepreneurship. In J.P. Walsh \& A.P. Brief (Eds.), Academy of Management Annals, 3: 65-107. Essex, U.K.: Routledge.

Battilana, J., \& Dorado, S. 2010. Building sustainable hybrid organizations: The case of commercial microfinance organizations. Academy of Management Journal, 53: 14191440.

Battilana, J., Lee, M., Walker, J., \& Dorsey, C. 2012. In search of the hybrid ideal. Stanford Social Innovation Review, Summer 2012: 51-56.

Bauer, T. N., Morrison, E. W., \& Callister, R. R. 1998. Organizational socialization: A review and directions for future research. Research in Personnel and Human Resources Management, 16: 149-214.

Ben-Ner, A. 2002. The shifting boundaries of the mixed economy and the future of the nonprofit sector. Annals of Public and Cooperative Economics, 73(1): 5-40.

Bentler, P.M., \& Bonnett, D.G. 1980. Significance tests and goodness of fit in analysis of covariance structures. Psychological Bulletin, 88: 588-606.

Benz, M. 2009. Entrepreneurship as a non-profit-seeking activity. International Entrepreneurship and Management Journal, 5(1): 23-44.

Berger, P. L., \& Luckmann, T. 1966. The social construction of reality: A treatise in the sociology of knowledge. New York, Doubleday. 
Besharov, M., \& Khurana, R. 2012. Leading Amidst Competing Institutional Demands: Revisiting Selznick's Conception of Leadership. Working Paper. Harvard Business School.

Bhattacharyya, O., Khor, S., McGahan, A., Dunne, D., Daar, A. S., Singer, P. A. 2010. Innovative health service delivery models in low and middle income countries-what can we learn from the private sector. Health Research Policy and Systems, 8(1): 24.

Bidwell, M., \& Briscoe, F. 2010. The dynamics of interorganizational careers. Organization Science, 21(5): 1034-1053.

Bourdieu, P. 1977. Outline of a theory of practice.

Bourdieu, P. \& Wacquant, L. 1992. An invitation to reflexive sociology.

Bowles, S., \& Gintis, H. 2011. Schooling in capitalist America: Educational reform and the contradictions of economic life. Haymarket Books.

Burton, M. D., Sørensen, J. B., \& Beckman, C. M. 2002. Coming from good stock: Career histories and new venture formation. In M. Lounsbury \& M. J. Ventresca (Eds.), Research in the Sociology of Organizations: 229-262.

Chao, G. T., O’Leary-Kelly, A. M., Wolf, S., Klein, H. J., \& Gardner, P. D. 1994. Organizational socialization: Its content and consequences. Journal of Applied Psychology, 79(5): 730.

Chen, K. K., \& O’Mahony, S. 2006. The selective synthesis of competing logics. Academy of Management Proceedings.

Cliff, J.E., Jennings, P.D., \& Greenwood, R. 2006. New to the game and questioning the rules: The experiences and beliefs of founders who start imitative vs. innovative firms. Journal of Business Venturing, 21(5): 633-663.

Coviello, N. E., \& Jones, M. V. 2004. Methodological issues in international entrepreneurship research. Journal of Business Venturing, 19(4): 485-508.

Dacin, P.A., Dacin, T.M., \& Matear, M. Social entrepreneurship: Why we don't need a new theory and how we move forward from here. Academy of Management Perspectives, 24(3): 37-57.

Dart, R. 2004. The legitimacy of social enterprise. Nonprofit Management and Leadership, 14(4): 411-424.

Davidsson, P., \& Honig, B. 2003. The role of social and human capital among nascent entrepreneurs. Journal of Business Venturing, 18(3): 301-331.

Dees, J. G. 1998. The meaning of social entrepreneurship. http://www.caseatduke.org/documents/dees_sedef.pdf. Accessed February 20, 2013.

Dees, J. G., \& Anderson, B. B. 2003. For-Profit Social Ventures. In M. L. Kourilsky \& W. B. Walstad (Eds.), Social Entrepreneurship. Senate Hall.

DiMaggio, P. J., \& Anheier, H. K. 1990. The sociology of nonprofit organizations and sectors. Annual Review of Sociology, 16: 137-159.

DiMaggio, P. J., \& Powell, W. W. 1983. The iron cage revisited: Institutional isomorphism and collective rationality in organizational fields. American Sociological Review, 48(2): 147160. 
DiRenzo, G. J. 1977. Socialization, personality, and social systems. Annual Review of Sociology, 3: 261-295.

Dobbin, F. 1994. Cultural models of organization: The social construction of rational organizing principles. In D.Crane (Ed.), The sociology of culture: Emerging theoretical perspectives, 117-42.

Dokko, G., Wilk, S.L. \& Rothbard, N.P. 2009. Unpacking prior experience: How career history affects job performance. Organization Science, 20(1): 51-68.

Drucker, P. F. 1989. What business can learn from nonprofits. Harvard Business Review, 67(4): 88-93.

Dunn, M. B., \& Jones, C. 2010. Institutional logics and institutional pluralism: The contestation of care and science logics in medical education, 1967-2005. Administrative Science Quarterly, 55(1): 114.

Eckhardt, J. T., \& Shane, S. A. 2003. Opportunities and Entrepreneurship. Journal of Management, 29(3): 333-349.

Eikenberry, A. M., \& Kluver, J. D. 2004. The marketization of the nonprofit sector: civil society at risk? Public Administration Review, 64(2): 132-140.

Emirbayer, M., \& Johnson, V. 2008. Bourdieu and organizational analysis. Theory and Society, 37(1): 1-44.

Evans, N. J., Forney, D. S., Guido, F. M., Patton, L. D., \& Renn, K. A. 2009. Student development in college: Theory, research, and practice. John Wiley \& Sons.

Feldman, D. C. 1981. The multiple socialization of organization members. Academy of Management Review, 6(2): 309-318.

Foster, W., \& Bradach, J. 2005. Should nonprofits seek profits? Harvard Business Review, 83(2): 92-100.

Friedland, R., \& Alford, R. R. 1991. Bringing society back in: Symbols, practices, and institutional contradictions. The New Institutionalism in Organizational Analysis: 232263. University Of Chicago Press.

Galaskiewicz, J., \& Barringer, S. 2012. Social enterprises and social categories. In J. Gidron \& Hasenfeld (Eds.), Social Enterprises: An Organizational Perspective. Palgrave/Macmillan.

Giddens, A. 1984. The constitution of society: Outline of the theory of structuration. Univ of California Press.

Glynn, M. A. 2000. When cymbals become symbols: Conflict over organizational identity within a symphony orchestra. Organization Science, 11(3): 285-298.

Gorsuch, R. L. 1997. Exploratory factor analysis: Its role in item analysis. Journal of Personality Assessment, 68(3): 532-560.

Greenwood, R., Raynard, M., Kodeih, F., Micelotta, E., \& Lounsbury, M. 2011. Institutional complexity \& organizational responses. Academy of Management Annals, 5. 317-371.

Gujarati, D. N. 2003. Basic Econometrics (4th edition.). New York: McGraw-Hill. 
Hall, P. D. 2006. A historical overview of philanthropy, voluntary associations, and nonprofit organizations in the United States, 1600-2000. In W.W. Powell \& R.S. Steinberg (Eds.), The nonprofit sector: A research handbook.

Handel, G., Cahill, S., \& Elkin, F. 2007. Children and society: The sociology of children and childhood socialization. Roxbury Publishing Company.

Hansmann, H. 1987. Economic theories of nonprofit organization. In W.W. Powell \& R.S. Steinberg (Eds.), The Nonprofit Sector: A Research Handbook.

Hansmann, H. B. 1980. The role of nonprofit enterprise. Yale Law Journal, 89(5): 835-901.

Haveman, H. A., \& Beresford, L. S. 2012. If you're so smart, why aren't you the boss? Explaining the persistent vertical gender gap in management. Annals of the American Academy of Political and Social Science, 639(1): 114-130.

Haveman, H. A., \& Rao, H. 2006. Hybrid forms and the evolution of thrifts. American Behavioral Scientist, 49(7): 974-986.

Heimer, C. A. 1999. Competing institutions: Law, medicine and family in neonatal intensive care. Law \& Society Review, 33(1): 17-66.

Higgins, M. C. 2005. Career imprints: Creating leaders across an industry. Jossey-Bass.

Haigh, N. \& Hoffman, A. 2012. Hybrid organizations: The next chapter of sustainable business. Organizational Dynamics, 41: 126-134.

Hsu, G., Koçak, Ö., \& Hannan, M. T. 2009. Multiple category memberships in markets: An integrative theory and two empirical tests. American Sociological Review, 74(1): 150169.

Hwang, H., \& Powell, W. W. 2009. The rationalization of charity: The influences of professionalism in the nonprofit sector. Administrative Science Quarterly, 54(2): 268298.

Janoski, T., \& Wilson, J. 1995. Pathways to voluntarism: Family socialization and status transmission models. Social Forces, 74(1): 271-292.

Jay, J. Forthcoming. Navigating paradox as a mechanism of change and innovation in hybrid organizations. Academy of Management Journal.

Johnson, Victoria. 2007. What is organizational imprinting? Cultural entrepreneurship in the founding of the Paris Opera. American Journal of Sociology, 113(1): 97-127.

Jones, S. R., \& Abes, E. S. 2004. Enduring influences of service-learning on college students' identity development. Journal of College Student Development, 45(2): 149-166.

Kacperczyk, A. J. 2009. Inside or Outside: The Social Mechanisms of Entrepreneurship Choices. Evidence from the Mutual Fund Industry. Doctoral dissertation. The University of Michigan.

Katz, J., \& Gartner, W. B. 1988. Properties of emerging organizations. Academy of Management Review, 429-441.

Khurana, R. 2010. From higher aims to hired hands: The social transformation of American management. 
Kohn, M. L., \& Schooler, C. 1983. Work and personality: An inquiry into the impact of social stratification. Norwood, NJ.

Kohn, M. L., Slomczynski, K. M., \& Schoenbach, C. 1986. Social stratification and the transmission of values in the family: A cross-national assessment. Sociological Forum 1(1): 73-102.

Kraatz, M. S., \& Block, E. S. 2008. Organizational implications of institutional pluralism. In R. Greenwood, C. Oliver, K. Sahlin-Andersson \& R. Suddaby (Eds.), The Sage handbook of organizational institutionalism, 840. London: Sage.

Lacy, W. B. 1978. Interpersonal relationships as mediators of structural effects: College student socialization in a traditional and an experimental university environment. Sociology of Education, 51: 201-211.

Light, P. 2008. The search for social entrepreneurship. Washington, D.C.: Brookings Institution.

London, T., \& Christiansen, M. 2008. VisionSpring: A lens for growth at the base of the pyramid. Case 1-428-610. William Davidson Institute: Ann Arbor, MI.

Maguire, S., Hardy, C., \& Lawrence, T. B. 2004. Institutional entrepreneurship in emerging fields: HIV/AIDS treatment advocacy in Canada. Academy of Management Journal, 47(5): 657-679.

Mair, J., \& Marti, I. 2006. Social entrepreneurship research: A source of explanation, prediction, and delight. Journal of World Business, 41(1): 36-44.

March, J., \& Simon, H. 1958. Organizations. New York: Wiley.

Marquis, C. \& Tilcsik, A. Forthcoming. Imprinting: Toward a multilevel theory. Academy of Management Annals.

Miller, D. R., \& Swanson, G. E. 1958. The Changing American Parent: A Study in the Detroit Area. Oxford, England: Wiley.

Moore, M. H. 2000. Managing for value: Organizational strategy in for-profit, nonprofit, and governmental organizations. Nonprofit and Voluntary Sector Quarterly, 29(1): 183-204.

Mustillo, S., Wilson, J., \& Lynch, S. M. 2004. Legacy volunteering: A test of two theories of intergenerational transmission. Journal of Marriage and Family, 66(2): 530-541.

Nunally, J.C. 1978. Psychometric theory, 2nd ed. New York: McGraw-Hill.

Pache, A. C., \& Santos, F. 2010. When worlds collide: The internal dynamics of organizational responses to conflicting institutional demands. Academy of Management Review, 35(3): 455-476.

Pache, A., \& Santos, Filipe. Forthcoming. Inside the hybrid organization: Selective coupling as a response to conflicting institutional logics. Academy of Management Journal.

Padgett, J. F., \& Powell, W. W. 2012. The emergence of organizations and markets. Princeton University Press, Princeton.

Parker, S. C. 2004. The economics of self-employment and entrepreneurship. Cambridge University Press. 
Powell, W.W., \& Colyvas. J.A. 2008. The microfoundations of institutions. In R. Greenwood, C. Oliver, K. Sahlin-Andersson, \& R. Suddaby (Eds.), Handbook of organizational institutionalism: 276-298. London: Sage.

Reynolds, P. D., \& White, S. B. 1997. The entrepreneurial process: Economic growth, men, women, and minorities. Quorum Books Westport, CT.

Ruef, M. 2005. Origins of organizations: The entrepreneurial process. Research in the Sociology of Work, 15: 63-100.

Rushing, W. 1974. Differences in profit and nonprofit organizations: A study of effectiveness and efficiency in general short-stay hospitals. Administrative Science Quarterly, 19(4): 474-484.

Saks, A. M., \& Ashforth, B. E. 1997. Organizational socialization: Making sense of the past and present as a prologue for the future. Journal of Vocational Behavior, 51(2): 234-279.

Schein, V. E. 2001. A global look at psychological barriers to women’s progress in management. Journal of Social Issues, 57(4): 675-688.

Schleef, D. J. 2006. Managing elites: Professional socialization in law and business schools. Rowman \& Littlefield Pub Incorporated.

Scott, W. R. 1987. The adolescence of institutional theory. Administrative Science Quarterly, 493-511.

Scott, W. R. 1994. Conceptualizing organizational fields: Linking organizations and societal systems. Systemrationalitat und Partialinteresse [Systems rationality and partial interests]: 203-221. Baden Baden, Germany: Nomos Verlagsgesellschaft.

Selznick, P. 1996. Institutionalism“ old” and“ new”. Administrative Science Quarterly, 270277.

Selznick, Philip. 1947. Leadership in administration: A sociological interpretation. Berkley, CA: University of California Press.

Seo, M. G., \& Creed, W. E. 2002. Institutional contradictions, praxis, and institutional change: A dialectical perspective. Academy of Management Review, 27(2): 222-247.

Shane, S. 2000. Prior knowledge and the discovery of entrepreneurial opportunities.

Organization Science, 11(4): 448-469.

Shane, S. 2003. A general theory of entrepreneurship: The individual-opportunity nexus. Edward Elgar Pub.

Shane, S., \& Venkataraman, S. 2000. The promise of entrepreneurship as a field of research. Academy of Management Review, 25(1): 217-226.

Short, J. C., Moss, T. W., \& Lumpkin, G. T. 2009. Research in social entrepreneurship: Past contributions and future opportunities. Strategic Entrepreneurship Journal, 3(2): 161194.

Stinchcombe, A. L. 1965. Social structure and organizations. In J.G. March (Ed.), Handbook of Organizations: 142-193. Chicago: Rand McNally. 
Snyder, T., \& Dillow, S. 2012. Digest of Education Statistics, 2011. Washington, D.C.: National Center for Education Statistics, Institute of Education Sciences, U.S. Department of Education.

Sørensen, J. B. 2007. Bureaucracy and entrepreneurship: Workplace effects on entrepreneurial entry. Administrative Science Quarterly, 52(3): 387-412.

Suddaby, R., \& Greenwood, R. 2005. Rhetorical strategies of legitimacy. Administrative Science Quarterly, 50(1): 35.

Swidler, A. 1986. Culture in action: symbols and strategies. American Sociological Review, 273-286.

Thornton, P. H., Ocasio, W., \& Lounsbury, Michael. 2012. The institutional logics perspective: Foundations, research, and theoretical elaboration. Oxford University Press.

Tilcsik, A. 2010. From ritual to reality: Demography, ideology, and decoupling in a postcommunist government agency. Academy of Management Journal, 53(6): 1474-1498.

Tilcsik, Andras. 2012. Remembrance of things past: Individual imprinting in organizations. Doctoral Dissertation. Harvard University.

Tracey, P., Phillips, N., \& Jarvis, O. 2011. Bridging Institutional Entrepreneurship and the Creation of New Organizational Forms: A Multilevel Model. Organization Science, 22(1): 60-80.

Tolbert, P.S. \& Zucker, L.G. 1996. The institutionalization of institutional theory. In S.R. Clegg, C. Hardy, \& W.R. Nord (Eds.), Handbook of Organization Studies: 175-190. London: Sage.

Trank, C. Q., \& Rynes, S. L. 2003. Who moved our cheese? Reclaiming professionalism in business education. Academy of Management Learning \& Education, 2(2): 189-205.

Van der Sluis, J., Van Praag, M., \& Vijverberg, W. 2008. Education and entrepreneurship selection and performance: A review of the empirical literature. Journal of Economic Surveys, 22(5): 795-841.

Van Maanen, J., \& Schein, E. H. 1979. Toward a theory of organizational socialization. Research in Organizational Behavior, 1(1): 209-264.

Weisbrod, B. A. 1977. The voluntary nonprofit sector. Lexington, MA: Lexington Books.

Young, D. R. 2009. Alternative perspectives on social enterprise. In J.J. Cordes \& C.E. Steuerle (Eds.), Nonprofits and Business, 21-46.

Zilber, T. B. 2002. Institutionalization as an interplay between actions, meaning and actors: the case of a rape crisis center in Israel. Academy of Management Journal, 45(1): 234-254.

Zuckerman, E. 1999. The categorical imperative: Securities analysts and the illegitimacy discount. American Journal of Sociology, 104(5): 1398-1438. 


\section{APPENDIX A: ITEMS MEASURING LOGICS}

Items measuring “ends” (commercial logic/social welfare logic)

(1) "My venture addresses an opportunity to make money/positively impact society" Items measuring "means” (commercial logic/social welfare logic)

(2) "I am personally working on my venture in order to make money/positively impact society"

(3) "Funders and/or investors provide financial capital to the venture in order to make money/positively impact society”

(4) "Employees and/or volunteers work for the venture in order to make money/positively impact society"

(5) "Customers and/or beneficiaries of the products or services that the venture creates are selected based on market forces/based on likely social impact”

(6) "Suppliers and other partner organizations (excluding funders/investors) work with the venture in order to make money/positively impact society” 
Table 1: Coded beneficiary groups

\begin{tabular}{|l|c|c|c|c|c|}
\hline Beneficiary Coding & Obs & Mean & Std. Dev. & Min & Max \\
\hline Elderly & 906 & 0.03 & 0.18 & 0 & 1 \\
\hline Alcohol and Drug Abusers & 906 & 0.01 & 0.10 & 0 & 1 \\
\hline Sexual Minorities & 906 & 0.01 & 0.11 & 0 & 1 \\
\hline Immigrants and Refugees & 906 & 0.04 & 0.18 & 0 & 1 \\
\hline Men & 906 & 0.07 & 0.25 & 0 & 1 \\
\hline Racial and Ethnic Minorities & 906 & 0.10 & 0.30 & 0 & 1 \\
\hline Incarcerated Populations & 906 & 0.03 & 0.17 & 0 & 1 \\
\hline Religious Groups & 906 & 0.01 & 0.11 & 0 & 1 \\
\hline Communities & 906 & 0.47 & 0.50 & 0 & 1 \\
\hline Civil Society & 906 & 0.11 & 0.31 & 0 & 1 \\
\hline Public & 906 & 0.31 & 0.46 & 0 & 1 \\
\hline Children & 906 & 0.23 & 0.41 & 0 & 1 \\
\hline Farmers & 906 & 0.13 & 0.33 & 0 & 1 \\
\hline Women & 906 & 0.23 & 0.42 & 0 & 1 \\
\hline Youth & 906 & 0.39 & 0.49 & 0 & 1 \\
\hline Families & 906 & 0.23 & 0.42 & 0 & 1 \\
\hline Disabled & 906 & 0.10 & 0.30 & 0 & 1 \\
\hline Poor & 906 & 0.32 & 0.47 & 0 & 1 \\
\hline Government & 906 & 0.05 & 0.22 & 0 & 1 \\
\hline Homeless & 906 & 0.02 & 0.15 & 0 & 1 \\
\hline Students & 906 & 0.19 & 0.39 & 0 & 1 \\
\hline School & 906 & 0.11 & 0.32 & 0 & 1 \\
\hline Health Providers & 906 & 0.03 & 0.16 & 0 & 1 \\
\hline & & & & & \\
\hline
\end{tabular}


Table 2: Correlations and descriptive statistics

\begin{tabular}{|c|c|c|c|c|c|c|c|c|c|c|c|c|c|c|c|c|c|c|c|}
\hline & & Mean & S.D. & 1 & 2 & 3 & 4 & 5 & 6 & 7 & 8 & 9 & 10 & 11 & 12 & 13 & 14 & 15 & 16 \\
\hline 1 & Venture hybridity (dependent variable) & 447.00 & 185.09 & 1.00 & & & & & & & & & & & & & & & \\
\hline 2 & Parent's for-profit work experience & 0.56 & 0.50 & 0.12 & 1.00 & & & & & & & & & & & & & & \\
\hline 3 & Business education & 0.28 & 0.45 & 0.10 & 0.06 & 1.00 & & & & & & & & & & & & & \\
\hline 4 & Own for-profit work experience (in years) & 6.39 & 8.06 & 0.11 & 0.19 & 0.12 & 1.00 & & & & & & & & & & & & \\
\hline 5 & Own for-profit work experience squared & 105.67 & 231.33 & 0.07 & 0.13 & 0.05 & 0.93 & 1.00 & & & & & & & & & & & \\
\hline 6 & Age & 37.85 & 10.96 & -0.03 & -0.07 & 0.06 & 0.47 & 0.47 & 1.00 & & & & & & & & & & \\
\hline 7 & Gender & 0.61 & 0.49 & 0.09 & -0.15 & 0.02 & -0.08 & -0.05 & -0.06 & 1.00 & & & & & & & & & \\
\hline 8 & Milestones reached & 3.46 & 1.22 & 0.01 & 0.00 & 0.01 & 0.01 & 0.03 & -0.01 & -0.01 & 1.00 & & & & & & & & \\
\hline 9 & Applied in 2011 & 0.49 & 0.50 & -0.01 & 0.04 & 0.01 & -0.05 & -0.04 & -0.07 & -0.09 & 0.15 & 1.00 & & & & & & & \\
\hline 10 & Arts and Culture & 0.04 & 0.19 & -0.03 & 0.07 & -0.07 & 0.03 & 0.03 & -0.03 & -0.01 & -0.02 & -0.01 & 1.00 & & & & & & \\
\hline 11 & Civil and Human Rights & 0.09 & 0.28 & -0.19 & 0.01 & -0.05 & -0.07 & -0.07 & -0.02 & -0.05 & 0.04 & 0.07 & -0.06 & 1.00 & & & & & \\
\hline 12 & Economic Development & 0.32 & 0.47 & 0.16 & -0.07 & 0.06 & -0.01 & 0.00 & 0.04 & 0.03 & -0.01 & -0.11 & -0.13 & -0.21 & 1.00 & & & & \\
\hline 13 & Education & 0.25 & 0.43 & -0.10 & 0.02 & -0.01 & 0.03 & 0.00 & 0.00 & -0.02 & -0.06 & -0.10 & -0.11 & -0.18 & -0.40 & 1.00 & & & \\
\hline 14 & Environment & 0.11 & 0.31 & 0.14 & -0.03 & 0.00 & -0.01 & 0.00 & 0.00 & 0.06 & 0.04 & 0.06 & -0.07 & -0.11 & -0.24 & -0.20 & 1.00 & & \\
\hline 15 & Health/Healthcare & 0.07 & 0.26 & -0.03 & 0.02 & -0.03 & 0.00 & -0.01 & 0.02 & 0.01 & 0.03 & 0.07 & -0.06 & -0.09 & -0.19 & -0.16 & -0.10 & 1.00 & \\
\hline 16 & Public Service & 0.12 & 0.33 & -0.02 & 0.03 & 0.03 & 0.02 & 0.05 & -0.03 & -0.03 & 0.00 & 0.12 & -0.07 & -0.11 & -0.26 & -0.22 & -0.13 & -0.11 & 1.00 \\
\hline
\end{tabular}


Table 3: Hybrid social ventures as an outcome of imprinting

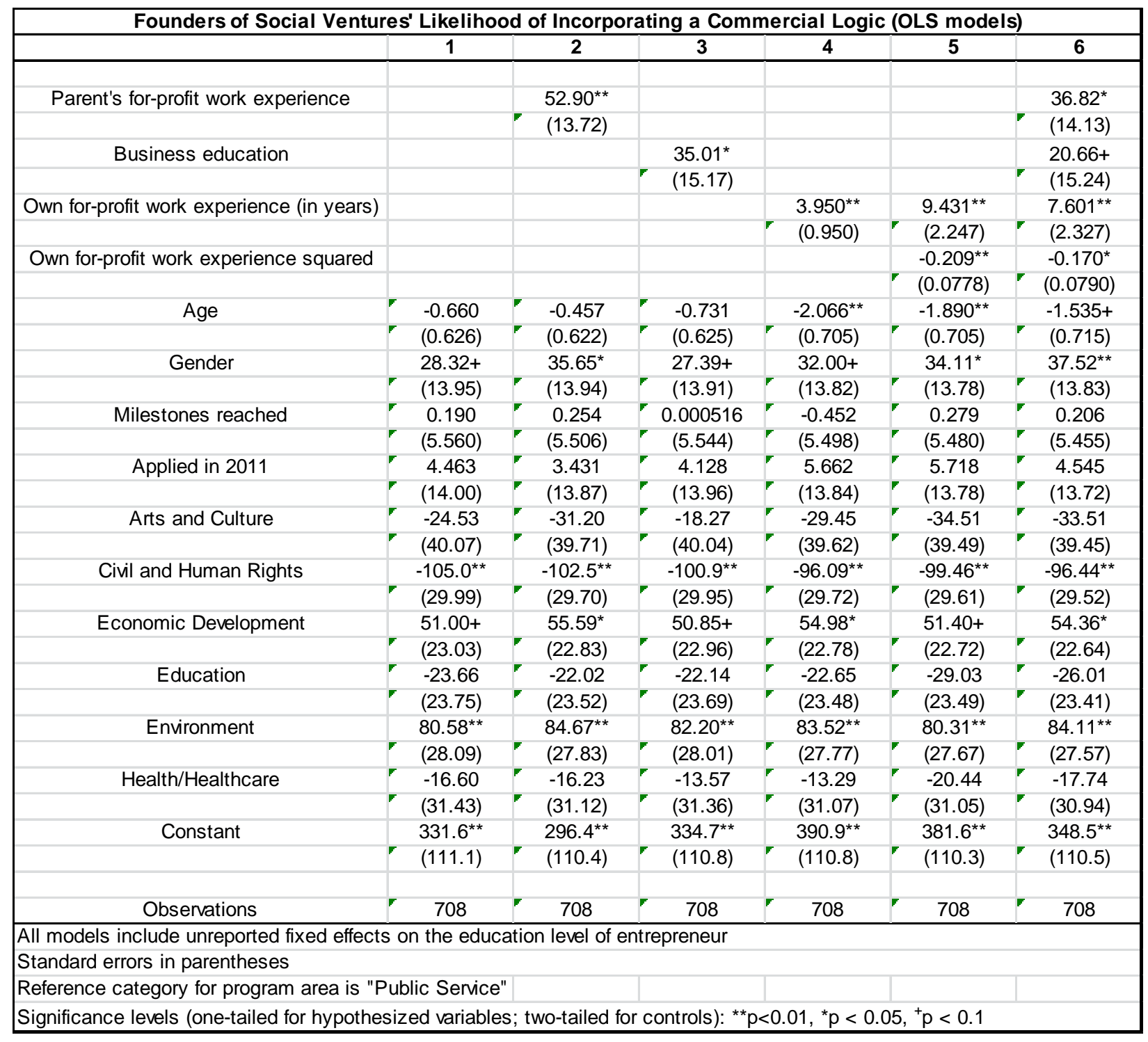


Table 4: Hybrid social ventures as an outcome of imprinting (binary dependent variable)

\begin{tabular}{|c|c|c|c|c|c|c|}
\hline \multicolumn{7}{|c|}{ Founders of Social Ventures' Likelihood of Incorporating a Commercial Logic (Logistic models) } \\
\hline & 1 & 2 & 3 & 4 & 5 & 6 \\
\hline \multirow[t]{2}{*}{ Parent's for-profit work experience } & & $1.002^{\star \star}$ & & & & $0.780 * \star$ \\
\hline & & $(0.239)$ & & & & $(0.249)$ \\
\hline \multirow[t]{2}{*}{ Business education } & & & $0.594^{\star \star}$ & & & $0.393^{*}$ \\
\hline & & & $(0.224)$ & & & $(0.235)$ \\
\hline \multirow[t]{2}{*}{ Own for-profit work experience (in years) } & & & & $0.0522^{\star *}$ & $0.139 * *$ & $0.104^{\star *}$ \\
\hline & & & & $(0.0146)$ & $(0.0369)$ & $(0.0380)$ \\
\hline \multirow{2}{*}{ Own for-profit work experience squared } & & & & & $-0.00311^{\star \star}$ & $-0.00238^{\star}$ \\
\hline & & & & & $(0.00125)$ & $(0.00126)$ \\
\hline \multirow[t]{2}{*}{ Age } & 0.00225 & 0.00599 & 0.00170 & -0.0204 & -0.0174 & -0.00836 \\
\hline & $(0.00969)$ & $(0.00963)$ & $(0.00983)$ & $(0.0123)$ & $(0.0123)$ & $(0.0123)$ \\
\hline \multirow[t]{2}{*}{ Gender } & 0.232 & $0.393+$ & 0.223 & 0.296 & 0.350 & $-0.0204+$ \\
\hline & $(0.225)$ & $(0.231)$ & $(0.226)$ & $(0.228)$ & $(0.231)$ & $(0.236)$ \\
\hline \multirow[t]{2}{*}{ Milestones reached } & -0.0298 & -0.0230 & -0.0332 & -0.0500 & -0.0449 & -0.0339 \\
\hline & $(0.0861)$ & $(0.0882)$ & $(0.0866)$ & $(0.0872)$ & $(0.0879)$ & $(0.0896)$ \\
\hline \multirow[t]{2}{*}{ Applied in 2011} & 0.0793 & 0.0574 & 0.0709 & 0.0950 & 0.103 & 0.0624 \\
\hline & $(0.220)$ & $(0.222)$ & $(0.222)$ & $(0.223)$ & $(0.225)$ & $(0.226)$ \\
\hline \multirow[t]{2}{*}{ Arts and Culture } & -0.237 & -0.361 & -0.145 & -0.312 & -0.392 & -0.389 \\
\hline & $(0.692)$ & $(0.699)$ & $(0.697)$ & $(0.704)$ & $(0.703)$ & $(0.710)$ \\
\hline \multirow[t]{2}{*}{ Civil and Human Rights } & $-1.505+$ & $-1.450+$ & $-1.455+$ & $-1.373+$ & $-1.461+$ & $-1.376+$ \\
\hline & $(0.786)$ & $(0.791)$ & $(0.788)$ & $(0.790)$ & $(0.793)$ & $(0.796)$ \\
\hline \multirow[t]{2}{*}{ Economic Development } & 0.506 & $0.613+$ & 0.494 & 0.587 & 0.523 & 0.590 \\
\hline & $(0.362)$ & $(0.366)$ & $(0.364)$ & $(0.367)$ & $(0.369)$ & $(0.373)$ \\
\hline \multirow[t]{2}{*}{ Education } & -0.233 & -0.209 & -0.219 & -0.205 & -0.323 & -0.263 \\
\hline & $(0.398)$ & $(0.401)$ & $(0.400)$ & $(0.403)$ & $(0.407)$ & $(0.410)$ \\
\hline \multirow[t]{2}{*}{ Environment } & 0.670 & $0.782+$ & $0.697+$ & $0.749+$ & 0.693 & $0.784+$ \\
\hline & $(0.413)$ & $(0.420)$ & $(0.416)$ & $(0.419)$ & $(0.421)$ & $(0.427)$ \\
\hline \multirow[t]{2}{*}{ Health/Healthcare } & -0.0411 & -0.0289 & -0.00455 & 0.0195 & -0.117 & -0.0953 \\
\hline & $(0.516)$ & $(0.521)$ & $(0.519)$ & $(0.521)$ & $(0.526)$ & $(0.533)$ \\
\hline \multirow[t]{2}{*}{ Constant } & $-1.739 \star \star$ & $-2.614^{\star \star}$ & $-1.931^{\star \star}$ & $-1.332+$ & $-1.674^{*}$ & $-2.554^{\star \star}$ \\
\hline & $(0.670)$ & $(0.715)$ & $(0.686)$ & $(0.696)$ & $(0.709)$ & $(0.765)$ \\
\hline Observations & 698 & 698 & 698 & 698 & 698 & 698 \\
\hline \multicolumn{7}{|c|}{ All models include unreported fixed effects on the education level of entrepreneur } \\
\hline \multicolumn{7}{|l|}{ Standard errors in parentheses } \\
\hline \multicolumn{3}{|c|}{ Reference category for program area is "Public Service" } & & & & \\
\hline Significance levels (one-tailed for hypothe & esized variabl & les; & & ${ }^{*} \mathrm{p}$ & & 0.1 \\
\hline
\end{tabular}


Table 5: Supplementary analyses: Effects of additional imprints

\begin{tabular}{|c|c|c|c|c|c|c|c|c|c|}
\hline \multicolumn{10}{|c|}{ Founders of Social Ventures' Likelihood of Incorporating a Commercial Logic (OLS models) } \\
\hline & 1 & 2 & 3 & 4 & 5 & 6 & 7 & 8 & 9 \\
\hline \multirow[t]{2}{*}{ Parent's for-profit work experience } & & $52.85^{\star \star}$ & $63.22^{\star \star}$ & & & & & & \\
\hline & & $(13.74)$ & $(15.86)$ & & & & & & \\
\hline \multirow[t]{2}{*}{ Parent's non-profit work experience } & & 15.43 & $38.64+$ & & & & & & \\
\hline & & $(15.55)$ & $(23.61)$ & & & & & & \\
\hline \multirow[t]{2}{*}{$\begin{array}{l}\text { Parent's for-profit work experience } X \\
\text { Parent's non-profit work experience }\end{array}$} & & & $-40.64+$ & & & & & & \\
\hline & & & $(31.11)$ & & & & & & \\
\hline \multirow[t]{2}{*}{ Business education } & & & & $31.39^{*}$ & $42.15^{\star \star}$ & & & & \\
\hline & & & & $(15.19)$ & $(16.59)$ & & & & \\
\hline \multirow[t]{2}{*}{ Social welfare education } & & & & $-41.99^{\star \star}$ & $-27.38+$ & & & & \\
\hline & & & & $(17.62)$ & $(19.81)$ & & & & \\
\hline \multirow[t]{2}{*}{$\begin{array}{c}\text { Business education } X \text { social welfare } \\
\text { education }\end{array}$} & & & & & $-65.98+$ & & & & \\
\hline & & & & & $(41.12)$ & & & & \\
\hline \multirow[t]{2}{*}{ Own for-profit work experience (in years) } & & & & & & $3.851^{\star \star}$ & $2.799^{\star}$ & $9.563^{\star \star}$ & $9.538^{\star \star}$ \\
\hline & & & & & & $(0.980)$ & $(1.246)$ & $(2.271)$ & $(2.275)$ \\
\hline \multirow[t]{2}{*}{ Own for-profit work experience squared } & & & & & & & & $-0.274^{\star \star}$ & $-0.247^{\star \star}$ \\
\hline & & & & & & & & $(0.0836)$ & $(0.0813)$ \\
\hline \multirow[t]{2}{*}{$\begin{array}{l}\text { Own non-profit work experience } \\
\text { (in years) }\end{array}$} & & & & & & -0.496 & -1.780 & -1.663 & 2.133 \\
\hline & & & & & & $(1.208)$ & $(1.530)$ & $(1.353)$ & $(2.825)$ \\
\hline \multirow[t]{2}{*}{ Own non-profit work experience squared } & & & & & & & & & $-0.168+$ \\
\hline & & & & & & & & & $(0.128)$ \\
\hline \multirow[t]{2}{*}{$\begin{array}{l}\text { Own for-profit work experience X own } \\
\text { non-profit work experience }\end{array}$} & & & & & & & $0.155^{+}$ & & \\
\hline & & & & & & & $(0.113)$ & & \\
\hline \multirow[t]{2}{*}{$\begin{array}{l}\text { Own for-profit work experience squared } \mathrm{X} \\
\text { own non-profit work experience }\end{array}$} & & & & & & & & $0.00786^{\star}$ & \\
\hline & & & & & & & & $(0.00368)$ & \\
\hline \multirow[t]{2}{*}{$\begin{array}{l}\text { Own for-profit work experience squared X } \\
\text { own non-profit work experience squared }\end{array}$} & & & & & & & & & $0.000261^{*}$ \\
\hline & & & & & & & & & $(0.000156)$ \\
\hline \multirow[t]{2}{*}{ Age } & -0.660 & -0.418 & -0.415 & -0.869 & -0.906 & $-1.922^{\star}$ & $-1.774+$ & $-1.546+$ & $-1.47+$ \\
\hline & $(0.626)$ & $(0.624)$ & $(0.624)$ & $(0.626)$ & $(0.625)$ & $(0.788)$ & $(0.795)$ & $(0.792)$ & $(0.803)$ \\
\hline \multirow[t]{2}{*}{ Gender } & $28.32+$ & $35.61^{*}$ & $36.35^{\star \star}$ & $24.56+$ & $23.9+$ & $31.57+$ & $30.57+$ & $32.27^{\star}$ & $33.2^{\star}$ \\
\hline & $(13.95)$ & $(13.97)$ & $(13.97)$ & $(13.92)$ & $(13.91)$ & $(13.87)$ & $(13.88)$ & $(13.81)$ & $(13.83)$ \\
\hline \multirow[t]{2}{*}{ Milestones reached } & 0.190 & -0.107 & -0.163 & 0.309 & 0.0364 & -0.455 & -0.351 & 0.188 & 0.187 \\
\hline & $(5.560)$ & $(5.526)$ & $(5.524)$ & $(5.527)$ & $(5.523)$ & $(5.502)$ & $(5.499)$ & $(5.470)$ & $(5.479)$ \\
\hline Applied in 2011 & 4.463 & 3.763 & 4.360 & 4.569 & 4.877 & 5.925 & 6.089 & 5.777 & 6.793 \\
\hline & $(14.00)$ & $(13.90)$ & $(13.90)$ & $(13.91)$ & $(13.90)$ & $(13.87)$ & $(13.86)$ & $(13.77)$ & $(13.80)$ \\
\hline Arts and Culture & -24.53 & -27.76 & -27.98 & -26.67 & -25.74 & -30.04 & -28.32 & -30.16 & -32.43 \\
\hline & $(40.07)$ & $(39.89)$ & $(39.87)$ & $(40.06)$ & $(40.01)$ & $(39.67)$ & $(39.67)$ & $(39.50)$ & $(39.52)$ \\
\hline Civil and Human Rights & $-105.00^{\star \star}$ & $-102.3^{\star \star}$ & $-102.7^{\star \star}$ & $-98.39^{\star \star \star}$ & $-100.2^{\star \star}$ & $-96.67^{\star \star}$ & $-97.06^{\star \star}$ & $-99.55^{\star \star}$ & $-99.85^{\star \star}$ \\
\hline & $(29.99)$ & $(29.72)$ & $(29.70)$ & $(29.86)$ & $(29.85)$ & $(29.77)$ & $(29.75)$ & $(29.58)$ & $(29.63)$ \\
\hline Economic Development & $51.00+$ & $56.61^{\star}$ & $57.45^{\star}$ & $49.25+$ & $49.37+$ & $54.30^{*}$ & $53.73^{\star}$ & $51.35+$ & $51.84+$ \\
\hline & (23.03) & $(22.87)$ & $(22.86)$ & (22.89) & $(22.87)$ & $(22.86)$ & (22.85) & $(22.73)$ & (22.78) \\
\hline Education & -23.66 & -21.80 & -22.51 & -26.80 & -26.86 & -23.35 & -23.88 & -29.34 & -27.79 \\
\hline & $(23.75)$ & (23.53) & (23.53) & (23.69) & $(23.66)$ & (23.55) & $(23.54)$ & $(23.50)$ & $(23.57)$ \\
\hline Environment & $80.58^{\star \star}$ & $85.27^{\star \star}$ & $85.43^{\star \star}$ & $82.68^{\star \star}$ & $80.81^{\star \star}$ & $82.73^{\star \star}$ & $80.45^{\star \star}$ & $77.74^{\star \star}$ & $78.89^{\star \star}$ \\
\hline & (28.09) & $(27.85)$ & $(27.84)$ & $(27.91)$ & $(27.91)$ & $(27.85)$ & $(27.89)$ & $(27.70)$ & $(27.75)$ \\
\hline Health/Healthcare & -16.60 & -15.15 & -15.84 & -19.12 & -17.76 & -14.20 & -13.58 & -19.66 & -18.22 \\
\hline & (31.43) & (31.15) & (31.14) & (31.34) & (31.31) & (31.17) & (31.15) & (31.06) & (31.15) \\
\hline Constant & $331.6^{\star \star}$ & $362.0^{\star \star}$ & $358.4^{\star *}$ & $343.4^{\star \star}$ & $347.1^{\star \star}$ & $387.4^{\star \star}$ & $387.8^{\star \star}$ & $376.2^{\star \star}$ & $358.7^{\star \star}$ \\
\hline & (111.1) & $(76.32)$ & (76.33) & $(110.5)$ & $(110.4)$ & $(111.2)$ & $(111.1)$ & $(110.4)$ & $(111.5)$ \\
\hline & & & & & & & & & \\
\hline \begin{tabular}{|c|} 
Observations \\
All models include unreported fixed effect
\end{tabular} & $\frac{708}{\text { s on the edu }}$ & $\frac{707}{\text { cation level o }}$ & $\frac{707}{\mathrm{f} \text { entrepreneu }}$ & 708 & 708 & 708 & 708 & 708 & 708 \\
\hline Standard errors in parentheses & & & & & & & & & \\
\hline Reference category for program area is " $\mathrm{P}$ & Public Servic & & & & & & & & \\
\hline Significance levels (one-tailed for hypothe & sized variabl & es; two-tail & for control & $:{ }^{\star \star} \mathrm{p}<0.01$ & $0.05,+$ & & & & \\
\hline
\end{tabular}

